\title{
INTRODUCTION TO THE SYMPOSIUM ON SERGIO PUIG AND GREGORY SHAFFER, "IMPERFECT ALTERNATIVES: INSTITUTIONAL CHOICE AND THE REFORM OF INVESTMENT LAW," AND ANTHEA ROBERTS, “INCREMENTAL, SYSTEMIC, AND PARADIGMATIC REFORM OF INVESTOR-STATE ARBITRATION”
}

\author{
Laurence Boisson de Chazournes*
}

The need for reform in the field of investment disputes has become something of a mantra in political, diplomatic, and legal circles. While many would agree that change is necessary, its nature and scope are much more contested. Various proposals have been made, some more ambitious than others, and for different reasons. Their rationales are rarely detailed, making it difficult to understand the pros and cons of each, as well as their contribution to furthering the rule of law.

In this context, the American Journal of International Law recently published two pieces that make significant contributions to understanding the landscape of international investment law reform. The first, an article by Sergio Puig and Gregory Shaffer, inventories a wide range of possible processes for resolving investment disputes and engages in a comparative institutional analysis to evaluate the trade-offs among them. ${ }^{1}$ This piece starts from the premise that each institutional process exhibits relative biases, and then uses accountability under the rule of law as the standard for assessing the trade-offs. Without privileging any single institutional process, the article makes two main arguments. The first is that reforms should address the complementarity between domestic and international institutions. The second is that institutional choice should vary in light of the different contexts states face in terms of capital endowments, market size, and institutional development, among other conditions.

The second contribution, an essay by Anthea Roberts, draws upon the author's close involvement with the UN Commission on International Trade Law (UNCITRAL) Working Group III's ongoing discussions on investor-state dispute settlement to suggest that there is not yet any convergence among participating states on which reforms to pursue. ${ }^{2}$ In an effort to shed light on this situation, Roberts classifies states into three groups according to their positions on reform: First, incrementalists view critiques of the current system as exaggerated and argue that investor-state arbitration remains the best option available. These states favor modest reforms to address specific concerns. Second, systemic reformers seek to retain investors' ability to file claims directly at the international level, but they also push for significant reforms, such as replacing investor-state arbitration with a multilateral investment court or an appellate body. Third, paradigm shifters dismiss the existing system as irrevocably flawed and in need of complete replacement. These states reject the utility of international claims against states and ask for alternatives. Roberts addresses the various strategies at stake and highlights that there is room for flexibility among and within the various positions.

The essays in this symposium respond to these contributions in various ways. Catharine Titi starts by critiquing the assumption that the reform process will produce a single outcome. ${ }^{3}$ The options are many, and she suggests that

* Professor, University of Geneva; Member of the AJIL Board of Editors.

${ }^{1}$ Sergio Puig \& Gregory Shaffer, Imperfect Alternatives: Institutional Choice and the Reform of Investment Law, 112 AJIL 361 (2018).

2 Anthea Roberts, Incremental, Systemic, and Paradigmatic Reform of Investor-State Arbitration, 112 AJIL 410 (2018).

${ }^{3}$ Catherine Titi, Who's Afraid of Reform? Beware the Risk of Fragmentation, 112 AJIL UnBound 232 (2018).

\footnotetext{
The American Society of International Law and Laurence Boisson de Chazournes (C) 2018. This is an Open Access article, distributed under the terms of the Creative Commons Attribution licence (http://creativecommons.org/licenses/by/4.0/), which permits unrestricted re-use, distribution, and reproduction in any medium, provided the original work is properly cited.
} 
there is a thin line between what constitutes a good option and what constitutes a better alternative. This is particularly the case if, as Puig and Shaffer contend, protecting the rule of law is the overarching goal. Titi draws from treaty and state practice as well as state reform proposals to show how the investor-state dispute settlement (ISDS) landscape is fragmented. She does not argue that this condition renders a coordinated, single solution impossible, but rather that fragmentation reveals the difficulties that will have to be surmounted to reach such a solution in the future.

Wolfgang Alschner agrees with Puig and Shaffer's emphasis on the need to find the right combination of complementary institutions, but contends that institutional complementarity goes beyond the interplay of municipal courts and international tribunals. ${ }^{4}$ In his view, complementarity should also include a variety of possible combinations of judicial, non-judicial, domestic, and international reform alternatives. Because state visions and interests differ, Alschner suggests that institutional choices on investment law reform should be made only after a period of experimentation, rather than imposed on states prematurely. He notes that unprecedented change, innovation, and experimentation are taking place in investment treaty design at the bilateral and regional levels, and that more states are participating as active rule-makers. This situation makes it harder to find common ground and leads Alschner to join Puig and Shaffer, as well as Roberts, in suggesting that pluralism and flexibility are, at least for now, important features of investment law reform. In Alschner's view, these features offer the best chance at a desirable multilateral reform of ISDS in the long run.

Wenhua Shan and Yunya Feng call for states to employ a so-called trinity analytical framework in considering ISDS reform, as well as in the context of UNCITRAL discussions. ${ }^{5}$ Such a trinity relies on three key pillars: the methods, subjects, and objects of investment disputes. The innovation here is that, in addition to the "methods" of investment dispute resolution analyzed by Puig and Shaffer, and the "subjects" or states that Roberts has grouped into three categories, Shan and Feng propose to add a third pillar of "objects" - that is, the disputes per se. Shan and Feng contend that the third pillar is important because it is impossible to fully appreciate how ISDS should be reformed without understanding the investment disputes that are at stake. Because these disputes are varied, the authors argue that states should devise different and context-dependent methods of resolution. This leads Shan and Feng to suggest that international adjudicatory mechanisms should be reformed. It also leads them to conclude that, for certain disputes, foreign investors should be able to resort to international adjudication as an alternative to domestic courts and not as a complement, contra the recommendation of Puig and Shaffer.

Patrick Pearsall explains that the state has a tripartite role in investment protection and promotion: ${ }^{6}$ (1) It is a law-giver through its rule-making function. (2) It is a protector of investment through the establishment of transnational obligations and an efficient dispute-settlement mechanism. (3) It is a respondent through its offer in international investment agreements to arbitrate disputes. Pearsall aims to show that the way a state calibrates these various roles offers insight into how it will approach different trade-offs among and within the institutional processes described by Puig and Shaffer, and Roberts. As the key actors in the reform process, states decide whether or not the system of international adjudication will persist and on what terms. Pearsall submits that states will test the various proposed innovations against their tripartite role in the investment law domain.

Sadie Blanchard welcomes Puig and Shaffer's effort to take stock of trade-offs among institutional processes, but draws attention to the risks of comparative institutional analysis. ${ }^{7}$ She emphasizes theoretical weaknesses, such as Puig and Shaffer's presumption that collective action problems hinder organization only for those who stand to

\footnotetext{
${ }^{4}$ Wolfgang Alschner, The Global Laboratory of Investment Law Reform Alternatives, 112 AJIL UnBound 237 (2018).

${ }^{5}$ Wenhua Shan and Yunya Feng, A Trinity Analytical Framework, for ISDS Reform, 112 AJIL UnBound 244 (2018).

${ }^{6}$ Patrick Pearsall, The Role of the State and the ISDS Trinity, 112 AJIL Unbound 249 (2018).

${ }^{7}$ Sadie Blanchard, The Limitations of Comparative Institutional Analysis, 112 AJIL UnBound 255 (2018).
} 
lose from stronger investment protection. She warns against conjecture on empirical questions, noting that there are divergent conclusions on whether investor-state arbitration and investment treaties actually increase foreign direct investment. Blanchard also argues that, on the question of whether alternative mechanisms such as a permanent investment court would affect investment flows, we cannot do better at this time than to speculate. She considers that institutions presented as alternatives can, in fact, be complementary, and she develops this point by looking at the relationships between reputation as a market mechanism and international litigation.

Finally, Jeremy Sharpe suggests that although international arbitration has long been the default mechanism for resolving international investment disputes, the traditional consensus in favor of arbitration has now given way, such that reform proposals abound. ${ }^{8}$ He stresses states' desire to exercise greater control over the regime for resolving international investment disputes, but notes that states also face significant problems of capacity, such as in their ability to efficiently defend against investor claims. Sharpe considers that the merits of any reform proposal, therefore, should be measured in part by its ability to improve state capacity to cope with the existing investment protection regime and rapidly changing developments in the field. There are issues of legitimacy attached to this quest. He suggests that one way for states to cope with current conditions would be to mandate that an intergovernmental organization provide the institutional support, training, and capacity-building to enable states to engage effectively in avoiding, mitigating, and managing international investment disputes.

A new reality underlies each of these essays: pluralism, flexibility, and experimentation have emerged as dominant features with respect to dispute settlement in international investment law. The possibilities seem endless. But in a broader sense, pluralism is nothing new. Indeed, it is evident that there has long been a preference for a variety of international courts and tribunals. ${ }^{9}$ Prior to the creation of international courts, arbitration was often the mechanism for resolving international disputes. The Hague Conferences of the nineteenth and twentieth centuries and the Statute of the Permanent Court of International Justice show that states aimed to maintain ad hoc arbitration while also creating permanent international judicial institutions for the first time. In this period, states similarly endeavored to establish other international courts alongside the Permanent Court of International Justice, such as the Central American Court of Justice and the proposed International Prize Court. After the Second World War, states continued to pursue plurality in international dispute settlement, preeminently symbolized in Article 33 of the UN Charter and the latitude it gives to states in settling their disputes by peaceful means.

Although experimentation and flexibility can bring welcome developments, there is a need to ensure the efficacy of the system. Undesirable consequences may arise from the coexistence of various institutional processes, including but not limited to abusive forum shopping, wasted resources, and conflicting decisions. It is interesting to note that this is not the prime concern in current discussions over institutional processes, however. Although it might be done behind the scenes, there is a need to think about coordinating tools and other mechanisms that can prevent undesirable consequences and that facilitate the implementation of various dispute-settlement mechanisms.

This can be done by including in treaties rules that organize relationships among international courts, tribunals, and other dispute-settlement mechanisms. Doing so would limit the need to rely on the goodwill of international adjudicators to prevent the risk of conflicting interpretations. One can also imagine other safeguards for ensuring a minimum level of consistency among the various investment decisions and awards, such as those foreseen in the World Trade Organization (WTO) Dispute Settlement Understanding. ${ }^{10}$ Indeed, the WTO provides a menu of dispute-settlement options enshrined within a framework of constraints that seeks to ensure coherence.

\footnotetext{
8 Jeremy Sharpe, Control, Capacity, and Legitimacy in Investment Treaty Arbitration, 112 AJIL UnBound 261 (2018).

${ }^{9}$ Laurence Boisson de Chazournes, The EJIL Foreword - Plurality in the Fabric of International Courts and Tribunals: Threads of a Managerial Approach, 28 Eur. J. InT'L L. 13 (2017).

${ }^{10}$ Understanding on Rules and Procedures Governing the Settlement of Disputes, Marrakesh Agreement Establishing the World Trade Organization, Annex 2, 1869 UNTS 401 (1994).
} 
It is true that, in the case of investment arbitration, states have freely opted into a system that arguably allows divergences where necessary, which is inherent in the very nature of ad hoc arbitration. This is one of the reasons behind the calls for an investment court or an appellate body. If these institutions are ultimately established, they will co-exist with other institutional processes, as discussed in the contributions by Puig and Shaffer, and Roberts. Communication among arbitral tribunals is usually understood as an act of considering earlier decisions, and it is often used as a way to promote consistency. States might reasonably expand such communication to encompass other dispute-settlement mechanisms.

An additional challenge in this context is linked to the growing emphasis on the resort to municipal jurisdictions. Whether the use of municipal fora is subsidiary or complementary to international institutional processes, there is a need to account for national voices. But what kind of communication should be favored? Pluralism and flexibility are laying the ground for a multilayered approach in the investment law area that requires careful reflection to ensure respect for the rule of law. 